\title{
The Effect of Enriched Organic Fertilizer and Methanol Spray on the Greenhouse-Tomato Yield
}

\author{
M. Afshari ${ }^{1}$, Gh. R. Afsharmanesh ${ }^{2} \&$ Khatoon Yousefi $^{3}$ \\ ${ }^{1}$ Islamic Azad University, Jiroft Branch, Jiroft, Iran \\ ${ }^{2}$ Jiroft Agricultural and Natural Resources Research Centre, Jiroft, Iran \\ ${ }^{3}$ Department of Agronomy and Plant Breeding, College of Agriculture, Shahid Bahonar University of Kerman, \\ Kerman, Iran
}

Correspondence: Khatoon Yousefi, Department of Agronomy and Plant Breeding, College of Agriculture, Shahid Bahonar University of Kerman, P.O. Box 76169-133, Kerman, Iran. E-mail: kh.yosefi@yahoo.com

\author{
Received: April 3, 2014 Accepted: July 22, 2014 Online Published: October 15, 2014 \\ doi:10.5539/jas.v6n11p14 URL: http://dx.doi.org/10.5539/jas.v6n11p14
}

\begin{abstract}
An experiment was conducted in the form of split-plot and random complete blocks with 3 repetitions in a greenhouse in Jiroft city of Kerman province, southeastern Iran, during 2011-2012 crop year, with the main aim to study how enriched organic fertilizer (chicken manure) and spraying methanol affects the quantity and quality of the yielding in Falcato tomato. Methanol and the enriched chicken manure as the two main and subordinate factors were studied in 4 levels $(0,20,30$, and 40 percentage of the volume) and $(0,500,1500$, and $2500 \mathrm{~kg} / \mathrm{ha})$. The results showed that the interaction of the two factors on the number of fruits per plant, the mean weight of fruit ( $\mathrm{p} \leq 0.05$ ), and the stem diameter $(\mathrm{p} \leq 0.01)$ was significant. Methanol $30 \%$ caused a $28 \%$ increase in yield, compared to the control plant. Adding $2500 \mathrm{~kg} / \mathrm{ha}$ chicken manure resulted in $31 \%$ increase in the yield in contrast to the control plant. Mean weight of a fruit in $40 \%$ methanol and $2500 \mathrm{~kg} / \mathrm{ha}$ chicken manure treatment was $145 \mathrm{~g}$. Finally, having evaluated all aspects and factors in this study, methanol $30 \%$ solution and $2500 \mathrm{~kg} / \mathrm{ha}$ chicken manure were recommended for Falcato tomato in greenhouses of Jiroft city.
\end{abstract}

Keywords: tomato, methanol, enriched chicken manure, stable farming, greenhouse

\section{Introduction}

Tomato (Lycopersicum esculentum L.) is one of the warm season fruits which is sensitive to cold. It is being cultivated in about 17000 ha of Jiroft and Kahnooj areas and an annually production of 450,000 tons, ranking the $3^{\text {rd }}$ tomato producer of the country, after Fars and Khorasan provinces. Increasing yield is a main aim that is very important for agricultural researchers. Photosynthesis is a main process to make organic matter at plants. Production dry matter rate has direct correlation to photosynthesis random rate and biostabilization mode of carbon dioxide at cultural plants. Today, most results indicate that using from simple alcohols such methanol causes to increase density of $\mathrm{CO}_{2}$ and totally increasing production and yield in three carbonic cultural plants (Ramirez et al., 2006) and decreasing induced stress cause to blocking respiration photo (Nonomura \& Benson, 1992). In generally, methanol spraying can decrease respiratory photo rate according to the $25 \%$ of plant carbon is consumed to photo respiratory and the reason of the process, this is that methanol speedily was metabolized to $\mathrm{CO}_{2}$ and water in plant tissues (Gout et al., 2000). Methanol chemisterical isomerilly is smaller than $\mathrm{CO}_{2}$ molecule, so it can absorb easily at three carbonic plants to increase photosynthesis (Aslani et al., 2011). Survey and more research for using methanol are essential due to benefic effects Several previous researchers have proved that spraying methanol increases plant yields and is considered as a carbon source for plants. Generally, one of the roles methanol plays is decreasing the inducted tensions to plants during photorespiration (Ramberget et al., 2002). Methanol is a familiar substance for plants because it is one of the simplest herbal products that many plants produce and spread especially during the first steps of leaf development due to demethylation pectin (Galbally \& Kirstine, 2002). This volatile organic compound emits through the leaf stomata and metabolizes the herbal tissues (Gout et al., 2000). $\mathrm{C}_{14}$-labeled Methanol enters the plant tissues immediately after being sprayed on their surface. This carbon is found in the Gluteus amino acid structure when the plant metabolism is influenced (Gout et al., 2000). 
Ivanova et al. (2001) reported that 10 to $50 \%$ methanol spray leads to an increase in plant growth which is believed to be related to the decrease in photorespiration as well as the increase in cell turgidity of herbal tissues. Moreover, methanol spraying indirectly excites Methyl trophic bacteria so that they will experience an increase in the growth process in plants through production of cytokinin and auxin (Ivanova et al., 2001). Remarkable increase in peanut and tomato yield by means of methanol spraying has been reported by Ramirez et al. (2006). Sadeghi-shoae et al. (2012) have studied the effect of spraying methanol on vetch yield and yield details, reporting that using $1 \%$ methanol is significant on the plant height and seed yield. The maximum yield of the seed is 1276 and $1241 \mathrm{~kg} / \mathrm{ha}$ resulted from $18 \%$ and $27 \%$ methanol, respectively while the maximum height obtained from $18 \%$ methanol is $56.25 \mathrm{~cm}$. In an experiment, Zbiec et al. (2003) studied the reaction of some plants against methanol in supplemental irrigation conditions and reported that tomato yield in low-Irrigation conditions and $20 \%$ and $30 \%$ methanol spraying resulted in 6.52 and $6.5 \mathrm{~kg} / \mathrm{ha}$, respectively while in normal-irrigation conditions, the maximum yields (6.6 and $7.16 \mathrm{~kg} / \mathrm{ha}$ ) resulted from $20 \%, 40 \%$, and $30 \%$ methanol spraying.

Using different fertilizers may lead to remarkable effects on yield and quality of the products as well (Toor et al., 2006). In many of the stable agricultural systems and especially bio-agriculture, organic fertilizers are being used in order to improve the soil conditions and productivity in addition to preventing and controlling herbal diseases and pests (Barker \& Bryson, 2006). In an experiment about qualitative criteria to produce organic and common tomato in Turkey conditions, Polat et al. (2010) studied and reported that the maximum yield of tomato in the first year could result in $77940 \mathrm{~kg} / \mathrm{ha}$ by using a combination of 50 tons of cow manure, $1.48 \mathrm{~kg} / \mathrm{ha}$ ormin-k organic acids, 3.2 ton/ha bone powder and 30 lit/ha Humex. In the second year, the tomato yield by the same treatment was about $92000 \mathrm{~kg} / \mathrm{ha}$. In an experiment, Jagadeesha (2008) studied the effect of organic and biotic fertilizers on tomato yield and reported significant difference between the treatments. The maximum number of fruits per plant was obtained to be 45 by using chemical fertilizer and 42 fruits per plant by using $50 \%$ manure plus 50\% vermin-compost. Moyin-jesu et al. (2012) reported a $48 \%$ increase in tomato fruit yield by using chicken manure. With regards to importance organic fertilizer on plant growth, this study was done in order to evaluate the effect of enriched organic fertilizer and methanol spraying on the greenhouse tomato yield.

\section{Materials and Methods}

The present research aims to study the effect of enriched organic fertilizer and methanol spraying on greenhouse tomato yield during 2011-2012 cropping year in Jiroft area located in N: $27^{\circ} 30^{\prime}$ and E: $57^{\circ} 25^{\prime}, 6259 \mathrm{~m}$ height above sea level. The experiment was conducted in the form of split plot and random complete blocks with 3 repetitions. The experiment treatments including methanol and the enriched chicken manure, as the main and subordinate plots, were studied in 4 levels $(0,20,30$, and 40 percentage of the volume) and $(0,500,1500$, and $2500 \mathrm{~kg} / \mathrm{ha}$ ), respectively. First, the soil sample was taken and it was proved that no chemical fertilizer had been used (Analysis of soil sample taken from 0-30 cm depth explained in Table 1). The seeds were cultivated from Aug. $23^{\text {rd }}$ to Sep. $6^{\text {th }}$ in a reservoir including tiny flowerpots and were transferred to the main land 45 days after germination.

There were 20 experimental treatments, 60 experimental plots, and each plot contained 5 plants cultivated every $50 \mathrm{~cm}$ in a line inside a $1 \mathrm{~m}$ wide, $2.5 \mathrm{~m}^{2}$ plot. Organic fertilizers were used simultaneously with the transplanting. Methanol was sprayed 4 times after pruning tomato plant at $30 \mathrm{~cm}$ and before flourishing, with a frequency of once in every 14 days. About $2 \mathrm{~g} / \mathrm{L}$ of glycerin was added to methanol treatment and the time of spraying was between 17:00 - 18:00. When the experiment was finished, the following attributes of the yield per area unit were measured: the numbers of fruit per plant, the average weight of a fruit, the dry weight of a fruit, water/flesh ratio, plant height, and stem diameter. To measure the quantitative attributes, picking was done manually 9 times in which the yields of the 5 plants in each plot were picked so that the number and weight of the fruits would be measured in each pick. Finally, the weight and number of all fruits in each plot were measured (through summing up the number and weight of the fruits within 9 picks). At the end and after collecting all data, the observations were statistically analyzed by SAS software (SAS Institute Inc. 2004) and the obtained averages were compared with one another, using the Duncan Multiple Range Test.

Table 1. Properties of the soil in experiment location

\begin{tabular}{cccccccc}
\hline Soil depth & $\mathrm{O} . \mathrm{C} \%$ & $\mathrm{~N} \%$ & $\mathrm{P}(\mathrm{ppm})$ & $\mathrm{K}(\mathrm{ppm})$ & $\mathrm{EC}(\mathrm{ds} / \mathrm{m})$ & $\mathrm{pH}$ & Soil texture \\
\hline $0-30$ & 0.113 & 0.017 & 4 & 320 & 1.3 & 7 & Sandy loam \\
\hline
\end{tabular}




\section{Results and Discussion}

The results proved that the effect of methanol on the fruit yield per hectare, the average weight of fruit, and water/flesh ratio of the fruit were all significant $(p \leq 0.05)$. The effect of enriched chicken manure on the fruit yield per hectare, the average weight of fruit $(\mathrm{p} \leq 0.01)$, the number of fruits per plant, the height/diameter ratio of the fruit, water/flesh ratio of the fruit, and plant height $(\mathrm{p} \leq 0.05)$ were significant (Table 2). The interaction between methanol spraying and enriched chicken manure on the average of stem diameter, the height/diameter ratio of the fruit $(\mathrm{p} \leq 0.01)$, the average weight of the fruit, and the number of fruits per plant $(\mathrm{p} \leq 0.05)$ were also significant (Table 2).

Table 2. Results of ANOVA for methanol solution concentration and chicken manure on tomato yield

\begin{tabular}{cccccccccc}
\hline SOV & Df & $\begin{array}{c}\text { Yield per } \\
\text { hectare }\end{array}$ & $\begin{array}{c}\text { Number of } \\
\text { fruits/plant }\end{array}$ & $\begin{array}{c}\text { Weight of } \\
\text { a fruit }\end{array}$ & $\begin{array}{c}\text { Height/diameter } \\
\text { ratio }\end{array}$ & $\begin{array}{c}\text { Water/flesh } \\
\text { ratio }\end{array}$ & Dry-weight & $\begin{array}{c}\text { Plant } \\
\text { height }\end{array}$ & $\begin{array}{c}\text { Stem } \\
\text { diameter }\end{array}$ \\
\hline Replication & 2 & 3423.17 & 0.4 & $1696.17^{*}$ & 0.003 & 1.3 & $5.63^{*}$ & 7.93 & 2.10 \\
Methanol & 3 & $53.58^{*}$ & $89.36 \mathrm{~ns}$ & $1709.9^{*}$ & $0.002 \mathrm{~ns}$ & $4.35^{*}$ & $5.97 \mathrm{~ns}$ & $85.68 \mathrm{~ns}$ & $4.69 \mathrm{~ns}$ \\
Error a & 6 & 1495.26 & 47.29 & 256.53 & 0.001 & 0.7 & 0.77 & 49.86 & 10.007 \\
Manure & 3 & $6347.69^{* *}$ & $97.87^{*}$ & $1401.8^{* *}$ & $0.095^{* *}$ & $2.64^{*}$ & $3.73 \mathrm{~ns}$ & $55.68^{*}$ & $5.73 \mathrm{~ns}$ \\
Interaction & 9 & $173.48 \mathrm{~ns}$ & $86.23^{*}$ & $436.8^{*}$ & $0.024^{* *}$ & $0.43 \mathrm{~ns}$ & $2.24 \mathrm{~ns}$ & $37.83 \mathrm{~ns}$ & $10.08^{* *}$ \\
Error b & 24 & 539.14 & 28.17 & 177.3 & 0.004 & 0.83 & 1.46 & 19.9 & 2.57 \\
CV\% & & 15.12 & 10.59 & 11.7 & 5.42 & 24.14 & 14.09 & 10.52 & 12.65 \\
\hline
\end{tabular}

1 - Ns $=$ Non significant and $*=p<0.05, * *=p<0.01$.

The increase in the percentage of methanol spraying up to $30 \%$ of the volume caused an increase in fruit yield per hectare. Afterwards, more increase in the methanol volume not only had no increasing effect on the yield but it also started to decrease it. The maximum fruit yield (185 ton/ha) resulted from methanol $30 \%$, leading to a 28 $\%$ increase in production, compared to that of the control group with 134 ton/ha (Table 3). In addition, such bacteria affect the nitrogen metabolism inside the plant through urea production. Therefore, the plants sprayed by methanol will increase nitrogen assimilation. The same analysis was reported by Ivanva et al. (2001) in which methanol spraying has led to a $50 \%$ increase in the activity of Nitrate-reductase enzyme in tomato and sugar beet and the resultant increase in yield.

Table 3. Means comparison effects of methanol and chicken manure tomato yield

\begin{tabular}{ccccccc}
\hline Treatment & Yield (ton/ha) & $\begin{array}{c}\text { Number of } \\
\text { fruits/plant }\end{array}$ & $\begin{array}{c}\text { Weight of a } \\
\text { fruit }(\mathrm{g})\end{array}$ & $\begin{array}{c}\text { Water/flesh } \\
\text { ratio }\end{array}$ & $\begin{array}{c}\text { Plant height } \\
(\mathrm{cm})\end{array}$ & Dry-weight\% \\
\hline Methanol (\%) & & & & & & \\
Control & $133.5 \mathrm{~b}^{1}$ & $49.13 \mathrm{a}$ & $100.4 \mathrm{~b}$ & $2.33 \mathrm{~b}$ & $292 \mathrm{c}$ & $8.1 \mathrm{~b}$ \\
20 & $147 \mathrm{ab}$ & $50.45 \mathrm{a}$ & $108.7 \mathrm{~b}$ & $3.21 \mathrm{a}$ & $293 \mathrm{ab}$ & $8.2 \mathrm{ab}$ \\
30 & $185.2 \mathrm{a}$ & $53.66 \mathrm{a}$ & $128.5 \mathrm{a}$ & $3.63 \mathrm{a}$ & $293 \mathrm{a}$ & $8.8 \mathrm{ab}$ \\
40 & $148.4 \mathrm{ab}$ & $47.17 \mathrm{a}$ & $116.0 \mathrm{ab}$ & $3.57 \mathrm{a}$ & $357 \mathrm{bc}$ & $9.3 \mathrm{a}$ \\
Manure (kg/ha) & & & & & $292 \mathrm{c}$ & $8.1 \mathrm{~b}$ \\
Control & $123.6 \mathrm{c}$ & 46.06 & $100.4 \mathrm{~b}$ & $2.67 \mathrm{~b}$ & $293 \mathrm{ab}$ & $8.2 \mathrm{ab}$ \\
500 & $153.1 \mathrm{~b}$ & $50.19 \mathrm{ab}$ & $113.4 \mathrm{ab}$ & $2.91 \mathrm{ab}$ & $293 \mathrm{ab}$ & $8.8 \mathrm{ab}$ \\
1500 & $157.9 \mathrm{~b}$ & $51.68 \mathrm{a}$ & $112.9 \mathrm{ab}$ & $3.65 \mathrm{a}$ & $293 \mathrm{ab}$ \\
2500 & $179.5 \mathrm{a}$ & $52.47 \mathrm{a}$ & $126,9 \mathrm{a}$ & $3.51 \mathrm{a}$ & $357 \mathrm{a}$ & $9.3 \mathrm{a}$ \\
\hline
\end{tabular}

${ }^{1}$ Columns means followed by the same letter are not significantly different at 0.05 probability level.

Zbiec et al. (2003) reported that in irrigated conditions, tomato yields $(6.6$ and $7.16 \mathrm{~kg} / \mathrm{m})$ resulted from a methanol spraying of $20 \%, 40 \%$, and $30 \%$, respectively. Moreover, the maximum yield of the vetch seed is 1276 and $1241 \mathrm{~kg} / \mathrm{ha}$, resulting from 18\% and 27\% methanol spraying, respectively (Sadeghi-shoae et al., 2012); our results in the experiment are in agreement with theirs. 
Having compared the average of the effect of enriched chicken manure on the yield of tomato fruit per hectare, it was proved that the increase in using enriched chicken manure leads to a remarkable increase in the yield of tomato fruit; in other words, using $500 \mathrm{~kg} / \mathrm{ha}$ chicken manure led to a remarkable yield in contrast to that of the control group which had no significant difference with using $1500 \mathrm{~kg} / \mathrm{ha}$. By increasing the chicken manure to $2500 \mathrm{~kg} / \mathrm{ha}$, the fruit yield increased remarkably. The maximum yield of the fruit was 180 ton $/$ ha by using 2500 $\mathrm{kg} / \mathrm{ha}$ enriched chicken manure and the minimum yield was observed in the control group (124 ton/ha). The difference between minimum and maximum was 33\% (Table 3). The organic fertilizers, thus, result in an increase in the yield by affecting the physicochemical attributes of the soil.

Carraera et al. (2007) reported the maximum yield of tomato fruit (100 tons) by using 5 ton/ha chicken manure. In the present study, however, although the interaction between using the enriched manure and methanol spraying was not significant on the yield of tomato fruit per hectare and the treatments showed similar process, the maximum yield of tomato fruit was obtained by using methanol $30 \%$ and different levels of enriched chicken manure. Along with the increase in using enriched chicken manure, the number of fruit per plant also increased. In other words, the maximum number of fruits per plant reached 53 fruits by using $2500 \mathrm{~kg} / \mathrm{ha}$ enriched fertilizer, which was not remarkably different from the conditions with using $1500 \mathrm{~kg} / \mathrm{ha}$. Using $500 \mathrm{~kg} / \mathrm{ha}$ enriched chicken manure and the control (i.e. without using enriched manure) did not show any remarkable difference regarding the fruit numbers per plant; using $2500 \mathrm{~kg} / \mathrm{ha}$ enriched chicken manure led to a $31 \%$ increase in number of fruits in contrast to the control group (Table 3). Comparing the average of the interaction between methanol spraying and using enriched chicken manure on the number of fruits per plant proved that the treatments did not show the same process on such attribute. In the treatment without methanol spraying, the number of fruits reached 53 by using $2500 \mathrm{~kg} / \mathrm{ha}$ enriched chicken manure. In the treatment with spraying $20 \%$ methanol, the maximum number reached 53 fruits by using $500 \mathrm{~kg} / \mathrm{ha}$ enriched chicken manure; using methanol $30 \%$ caused the maximum number of fruits to reach 64 and 58 when using $2500 \mathrm{~kg} / \mathrm{ha}$ and $1500 \mathrm{~kg} / \mathrm{ha}$ chicken manure, respectively (Table 4). Finally, the maximum number of fruits was obtained from the two above-mentioned treatments whereas the minimum number of fruits was obtained from the conditions without methanol spraying and without using enriched chicken manure. Amiri et al. (2011) reported that using chicken manure leads to $25 \%$ increase in the number of fruits per plant in contrast to the condition without using the manure. This result, too, is in accordance with the results of the present study.

Table 4. Means comparison of interaction effects of methanol and chicken manure tomato yield

\begin{tabular}{|c|c|c|c|c|c|c|}
\hline $\begin{array}{c}\text { Methanol } \\
(\%)\end{array}$ & $\begin{array}{l}\text { Chicken manure } \\
(\mathrm{kg} / \mathrm{ha})\end{array}$ & $\begin{array}{c}\text { Yield } \\
\text { (ton.ha-1) }\end{array}$ & $\begin{array}{l}\text { The number of } \\
\text { fruits per plant }\end{array}$ & $\begin{array}{l}\text { Weight of a fruit } \\
\text { (g) }\end{array}$ & $\begin{array}{c}\text { Height/diameter } \\
\text { ratio }\end{array}$ & $\begin{array}{l}\text { Stem diameter } \\
(\mathrm{mm})\end{array}$ \\
\hline \multirow{4}{*}{ Control } & 0 & $108.6 \mathrm{e}^{1}$ & $46.89 \mathrm{~cd}$ & $45.2 \mathrm{f}$ & $1.1 \mathrm{bcd}$ & $11.49 \mathrm{bc}$ \\
\hline & 500 & $132.2 \mathrm{de}$ & $47.61 \mathrm{~cd}$ & $104 \mathrm{c}-\mathrm{f}$ & $1.1 \mathrm{bcd}$ & $11.02 \mathrm{c}$ \\
\hline & 1500 & 139.9 cde & $50.33 \mathrm{bcd}$ & $102.8 \mathrm{c}-\mathrm{f}$ & $1.18 \mathrm{~b}$ & $9.97 \mathrm{c}$ \\
\hline & 2500 & $153.5 \mathrm{~b}-\mathrm{e}$ & $52.19 \mathrm{bc}$ & $109.5 \mathrm{c}-\mathrm{f}$ & $1.21 \mathrm{~b}$ & $14.61 \mathrm{a}$ \\
\hline \multirow{4}{*}{20} & 0 & $127.5 \mathrm{de}$ & $51.34 \mathrm{bc}$ & $92.27 \mathrm{def}$ & $1.03 \mathrm{~cd}$ & $15.08 \mathrm{a}$ \\
\hline & 500 & $149.1 \mathrm{~b}-\mathrm{e}$ & $53.44 \mathrm{bc}$ & $103.3 \mathrm{c}-\mathrm{f}$ & $1.17 \mathrm{~b}$ & $13.37 \mathrm{bc}$ \\
\hline & 1500 & $146.1 \mathrm{de}$ & $50 \mathrm{bcd}$ & $108.5 \mathrm{~b}-\mathrm{f}$ & $1.19 \mathrm{~b}$ & $11.63 \mathrm{c}$ \\
\hline & 2500 & $164.7 \mathrm{bcd}$ & $47 \mathrm{~cd}$ & $130.7 \mathrm{ab}$ & $1.17 \mathrm{~b}$ & $12.69 \mathrm{bc}$ \\
\hline \multirow{4}{*}{30} & 0 & $147.8 \mathrm{cde}$ & $40.78 \mathrm{~d}$ & $133.7 \mathrm{ab}$ & $0.99 \mathrm{a}$ & $12.93 \mathrm{bc}$ \\
\hline & 500 & $183.4 \mathrm{abc}$ & $51.33 \mathrm{bc}$ & $134.1 \mathrm{ab}$ & $1.2 \mathrm{~b}$ & $11.92 b c$ \\
\hline & 1500 & $193.5 \mathrm{ab}$ & $58.17 \mathrm{ab}$ & $123.6 \mathrm{abc}$ & $1.43 \mathrm{a}$ & $14.32 \mathrm{ab}$ \\
\hline & 2500 & $216.2 \mathrm{a}$ & $64.36 \mathrm{a}$ & $122.8 \mathrm{abc}$ & $1.03 \mathrm{~cd}$ & $12.62 \mathrm{bc}$ \\
\hline \multirow{4}{*}{40} & 0 & $110.7 \mathrm{e}$ & $45.22 \mathrm{~cd}$ & 90.54 ef & $1.03 \mathrm{~cd}$ & $15.03 \mathrm{a}$ \\
\hline & 500 & $147.6 \mathrm{cde}$ & $48.89 \mathrm{bcd}$ & $112.2 \mathrm{~b}-\mathrm{e}$ & $1.2 \mathrm{~b}$ & $14.12 \mathrm{ab}$ \\
\hline & 1500 & $151.6 \mathrm{~b}-\mathrm{e}$ & $48.22 \mathrm{bcd}$ & $116.5 \mathrm{~b}-\mathrm{e}$ & $1.22 \mathrm{~b}$ & $12 \mathrm{c}$ \\
\hline & 2500 & $183.6 \mathrm{abc}$ & $46.33 \mathrm{~cd}$ & $144.6 \mathrm{a}$ & $1.13 \mathrm{bc}$ & $10.09 \mathrm{bc}$ \\
\hline
\end{tabular}

\footnotetext{
${ }_{1}^{1}$ Columns means followed by the same letter are not significantly different at 0.05 probability level.
} 
Comparing the average effect of methanol on the average weight of fruit showed that the maximum weight of fruit (129 g) was obtained by spraying methanol 30\% while the minimum weight of fruit $(100 \mathrm{~g})$ was observed in the control group (i.e. the one without methanol spraying) (Table 3). The range of changes between the maximum and minimum weight of fruit was $28 \mathrm{~g}$; using $30 \%$ methanol spraying led to a $21 \%$ increase in fruit weight in comparison with the control group. Along with the increase in methanol concentration, the fruit weight significantly increased, reaching its maximum in the third level $(30 \%)$. Generally, using manure is more effective on the weight of tomato fruit, compared to the conditions without using it Although there was no significant difference between using $1500 \mathrm{~kg} / \mathrm{ha}-500 \mathrm{~kg} / \mathrm{ha}$ enriched chicken manure and the control group regarding the fruit weight, there still was significant difference between using $2500 \mathrm{~kg} / \mathrm{ha}$ enriched chicken manure and the control group regarding the fruit weight. The fruit weight showed an increase of approximately $20 \%$ in the treatment using $2500 \mathrm{~kg} / \mathrm{ha}$ enriched chicken manure, as compared to the treatment without using this manure. Comparing the average of interaction between methanol spraying and using enriched chicken manure proved that the maximum fruit weight obtained from $40 \%$ methanol spraying plus $2500 \mathrm{~kg} / \mathrm{ha}$ enriched chicken manure was $145 \mathrm{~g}$, which had no significant difference with the both treatments of $30 \%$ and $20 \%$ methanol plus $2500 \mathrm{~kg} / \mathrm{ha}$ enriched chicken manure. Different processes were observed regarding the above-mentioned attribute in treatments in which methanol spraying was not performed.

Amiri et al. (2011) reported that the total weight of plant fruits by using chicken manure increased more than the one in condition without using chicken manure. This result is in line with the results of the present experiment. Methanol spraying led to an increase in flesh/water ratio in the fruit; although there was not any significant difference among different levels of methanol spraying, they were relatively better than those of the control group. The maximum flesh/water ratio obtained from methanol $40 \%$ spraying was 3.57 (which shows a $34 \%$ increase more than control group). Therefore, it can be hypothesized that using methanol spraying will increase the flesh of tomato fruit in addition to decreasing its water ratio (which leads to production of more flesh and more durable tomatoes for market). Using the manure also led to an increase in flesh/water ratio: there was not any statistically significant difference between using $500 \mathrm{~kg} / \mathrm{ha}$ enriched chicken manure and the condition in the control group. Changes of the above-mentioned ratio between the maximum of using $2500 \mathrm{~kg} / \mathrm{ha}$ enriched chicken manure and the control group was approximately 0.84 . Using enriched chicken manure from second level $(500 \mathrm{~kg} / \mathrm{ha})$ on resulted in more flesh and more durable fruits.

The interaction between enriched chicken manure and methanol spraying on the fruit height/diameter ratio was significant (Table 2). Maximum value of this ratio (equal to 1.4) resulted from methanol $30 \%$ spraying along with using $1500 \mathrm{~kg} / \mathrm{ha}$ enriched chicken manure. The higher the height/diameter ratio becomes, the more the tomato shapes similar to a pear or an egg, which is very appropriate for market. Along with the increase in chicken manure up to the third level $(1500 \mathrm{~kg} / \mathrm{ha}$ enriched chicken manure), the dry-weight of the fruit did not show a statistically significant increase nor any difference with the control group. Using $2500 \mathrm{~kg} / \mathrm{ha}$ enriched chicken manure showed more dry-weight percentage of the fruit (about 9.30) which was a 13\% increase more than that of the control group (i.e. the one without using enriched chicken manure). The difference between minimum and maximum of the dry-weight percentage of the fruit was $1.2 \%$.

Comparing the average of the effect of enriched chicken manure on the plant height delineated that the maximum plant height is $357 \mathrm{~cm}$ when using $1500 \mathrm{~kg}$ enriched chicken manure (which is $65 \mathrm{~cm}$ higher in comparison to the height in the control group). Moyin-Jesu et al. (2012), in an experiment which used chicken manure, obtained the highest plant height (44/25) which was $19 / 40 \mathrm{~cm}$ higher than the control; their finding is the same as the results of the present study. Comparing the average of the interactions between enriched chicken manure usage and methanol spraying (Table 4) shows that by using methanol $20 \%$ and $40 \%$ and without using chicken manure and methanol (i.e. the control group) by using $1500 \mathrm{~kg} / \mathrm{ha}$ enriched chicken manure, the maximum stem diameter was obtained, with no meaningful difference with one another; they were, however, relatively better in comparison to the other treatments. By using enriched chicken manure with $20 \%$ methanol spraying, stem diameter increased to $15 \mathrm{~mm}$ which, in comparison to the stem diameter of the control group, was $3 / 5 \mathrm{~mm}$ thicker; Moyin-Jesu et al. (2010) have reported similar results as well. Generally and regarding to the attributes evaluated in this study, spraying methanol $30 \%$ and using $2500 \mathrm{~kg}$ chicken manure is strongly recommended for Falcato tomato in such conditions as Jiroft greenhouses.

\section{Conclusions}

The results in our project indicate that methanol spraying and chicken manure have significant effects on the measuring characters. Most yields are gathered by treatments methanol 30 percent volume and chicken manure $2500 \mathrm{~kg} / \mathrm{ha}$. Methanol increases plant growth due to it is carbon source and increase plant photosynthesis efficiency. Today, fertilizers such N, K, P and recently is considered by microelements such Fe, Zn, Cu but not 
allover could increase absorptive carbon at plant tissues. So, methanol can effect on the cultural plant's growth and yield by title increasing factor for absorption carbon and photosynthesis efficiency (Moosapoor, 2014). Chicken manure showed a positive effect on the yield and the quality of tomato fruits.

\section{References}

Amiri, M., Kocheki, B. A., Nasirai Mahallati, M., \& Jahan, M. (2011). The concomitant use of organic fertilizers and biological, in ecological production of tomato. Regional conference on strategies crop production and resource sustainability. Islamic Azad University of Astara.

Aslani, A., Safarzadeh Vishekaei, M. N., Farzi, M., Noorhosseini Niyaki, S. A., \& Jafari Paskiabi, M. (2011). Effects of foliar Applications of Methanol on Growth and Yield of Mung bean (Vigna radiata L.) in Rasht, Iran. African Journal of Agricultural Research, 6(15), 3603-3608.

Barker, A. V., \& Bryson, G. M. (2006). Comparisons of composts with low or high nutrient status for growth of plants in containers. Communic. Soil Sci. Plant Anal., 37, 1303-1319. http://dx.doi.org/10.1080/00103620600626460

Carrera, L. M., Buyer, T. S., Vinyard, B., Abdul-Bak, A. A., Sikoraand, L. J., \& Teasdale, T. R. (2007). Effects of cover crops, compost, and manure amendments on soil microbial community structure in tomato production systems. Applied Soil Ecoloyy, 37, 247-253. http://dx.doi.org/10.1016/j.apsoil.2007.08.003

Galbally, E., \& Kirstine, W. (2002). Production of methanol by flowers. Atmosphere, 43(3), 195-223.

Gout, E., Aubert, S., Bligny, R., Rebeille, F., \& Nonomura, A. R. (2000). Metabolism of methanol in plant cells. Archiv Carbon-13 nuclear magnetic resonance studies. Plant Physiology, 123, 287-296. http://dx.doi.org/10.1104/pp.123.1.287

Ivanova, E. C., Doronina, N. V., \& Trotsenko, Y. A. (2001). Aerobic methylobactria are capale of synthesizhng auxins. Microbioloyy, 40, 392-397. http://dx.doi.org/10.1023/A:1010469708107

Jagadeesha, V. (2008). Effect of organic manures and biofertilizerson growth, seed yield and quality in tomato (Lycopersicom esculentum mill.) cv. Megha. Thesis submitted to the University of Agricultural Sciences.

Moosapoor, N. (2014). Effect of iron fertilizer and methanol spraying on the soybean yield. Indian Journal of Fundamental and Applied Life Sciences, 4(1), 2231-6345.

Moyin-Jesu, E. I., \& Adekayode, F. O. (2010). Comparative Evaluation of Different Organic Fertilizers on SoilFertility Improvement, Leaf Mineral Composition and Growth Performance of African Cherry Nut (Chrysophyllum Albidium L.) Seedlings. J. Am. Sci., 6(8), 1.

Moyin-Jesu, M., O., \& Akinola M. O. (2012). Comparative evaluation of modified neem leaf and wood ash extracts on soil fertility status growth and fruit yield of tomato (Lyconpersicon esulentum L.). Global journal of bio-science \& biotechnology, 1(2), 271-276.

Nonomura, A. M., \& Benson, A. A. (1992). The path of carbon in photosynthesis: improved crop yields with methanol. Proceedings of the National Academy of Sciences of the United States of America, 89, 9794-9798. $\mathrm{http}: / / \mathrm{dx}$. doi.org/10.1073/pnas.89.20.9794

Polat, E., Demir, H., \& Erler, F. (2010). Yield and guality citeria in organically and conventionally growth

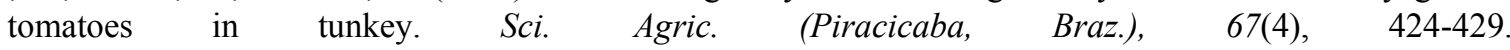
http://dx.doi.org/10.1590/S0103-90162010000400008

Ramberg, H. A., Bradley, J. S. C., Olson, J. S. C., Nishio, J. N., Markwell, J., \& Osterman, J. C. (2002). The role of methanol in promoting plant growth: An update. Plant Biochemistry and Biotechnology, 1, 113-126.

Ramirez, I., Drta, F., Espinoza, V., Jimenes, E., Mercado, A., \& Pena-cortes, H. (2006). Effects of foliar and root application of-methanol on the growth of Arabid opsis, Tobacco, and tomata plant. J. Plant Growth Regul., 25, 30-44. http://dx.doi.org/10.1007/s00344-005-0027-9

Sudghishoae, M., Paknejad, F., Kashani, A., Nooralvandiand, T., \& Tookalloo, M. R. (2012). Can foliar application with methanol improve the yield, yield? Components and physiological performance of mung bean (Vigna radiatul.). Annals of Biological Research, 3(10), 4780-4786.

Toor, R. K., Savage, G. P., \& Heeb, A. (2006). Influence of different types of fertilizers on the major antioxidant components of tomatoes. J. Food Comp. Anal., 19, 20-27. http://dx.doi.org/10.1016/j.jfca.2005.03.003

Zbiec, I., Karcsmar, S., \& Podsiadlo, C. (2003). Response of some cultivated plants to methanol as compared to supplemental irrigation. Electronic Journal of Polish Agricu/Tural Universities, 6, 1-7. 


\section{Copyrights}

Copyright for this article is retained by the author(s), with first publication rights granted to the journal.

This is an open-access article distributed under the terms and conditions of the Creative Commons Attribution license (http://creativecommons.org/licenses/by/3.0/). 